\title{
EFFECT OF SEED PRIMING TREATMENT ON THE PHYSIOLOGICAL QUALITY OF NATURALLY AGED ONION (ALLIUM CEPA L.) SEEDS
}

\author{
BRAR, N. S. ${ }^{1}-$ KAUSHIK, P. ${ }^{2,3^{*}}-$ DUDI, B. S. ${ }^{4}$ \\ ${ }^{1}$ Department of Vegetable Science, Punjab Agricultural University, Ludhiana 141 004, India \\ ${ }^{2}$ Instituto de Conservación y Mejora de la Agrodiversidad Valenciana, Universitat Politècnica \\ de València, Valencia 46022, Spain \\ ${ }^{3}$ Nagano University, 1088 Komaki, Ueda, Nagano 386-0031, Japan \\ ${ }^{4}$ Department of Vegetable Science, CCS Haryana Agricultural University, Hisar 125001, India \\ *Corresponding author \\ e-mail:prakau@doctor.upv.es,prashantumri@gmail.com; phone:+34-96-387-7000
}

(Received 10 $0^{\text {th }}$ Jul 2019; accepted $11^{\text {th }}$ Dec 2019)

\begin{abstract}
The experiment was conducted to investigate the effect of priming treatments on the physiological parameters of naturally aged onion (Allium cepa L.) seed, six seed priming treatments viz., Control, Hydro priming followed by dry dressing with Thiram $\left(2 \mathrm{~g} / \mathrm{kg}\right.$ ), Hydration with $\mathrm{GA}_{3}(50 \mathrm{ppm})$, Hydration with $\mathrm{KNO}_{3}$ (0.5\% solution), Hydration with $\mathrm{KH}_{2} \mathrm{PO}_{4}$ (0.5\% solution), and Biofertilizer (Azotobacter) were analyzed to identify the most suitable priming treatment. The standard seed germination, seedling length, seedling dry weight, seed vigour index-I \& II and viability test (Tz test), decreased significantly, while electrical conductivity increased with the advancement of the ageing period. The field parameters viz., seedling emergence index and seedling establishment also decreased significantly with the natural ageing of seeds. The seed quality improvement through seed priming was noticed more in marginal seed lot, i.e., oneyear-old seed lot. Among various priming treatments, hydration with GA3 @ 50 PPM followed by biofertilizer, (Azotobacter) performed best in enhancing all seed vigour and viability characteristics and lowering the electrical conductivity of naturally aged onion seeds. In conclusion, the present study revealed that onion seed loses its viability rapidly under ambient storage conditions. Therefore, seed priming with $\mathrm{GA}_{3} @ 50 \mathrm{ppm}$ and biofertilizer, (Azotobacter) can be used effectively to enhance its vigour and viability. These priming treatments can aid to improve the quality of seed stored for one year, thus ensuring good plant stands from the stored seed of a poor storer crop.
\end{abstract}

Keywords: onion, $G A_{3}$, Azotobacter, germination, viability, seedling emergence index

\section{Introduction}

Onion (Allium cepa L.) is a bulb crop of worldwide importance. India ranks first in the cultivated area with 1.31 million ha but ranks second in terms of total production (22.42 million tons) after China (FAO, 2017). Most crucial input for improving the yield is the use of good quality seeds. However, onion seeds exhibit some poor attributes like inferior longevity and storability, which ultimately result in rapid loss of viability (Khan et al., 2004). Furthermore, low-quality seeds result in low and asynchronous germination and high numbers of abnormal seedlings under stress conditions in early spring planting (Borowski and Michalek, 2006). Ultimately, quality of onion seed is dependent on several factors, some of which are surrounding environment during plant growth and seed development, location of seeds on plant, time of seed harvest, seed harvesting techniques, storage conditions and seed treatment before sowing. In the case of onions, where seed size is small, and seed establishment is 
poor, seed priming is the most promising method to improve seed establishment. Seed priming is a pre-sowing, controlled hydration treatment where physiological and biochemical activities are stimulated in the seed, but radicle protrusion is prevented (Khan, 1992). Bosland and Votara (2000) were of the view that priming leads to enhanced and uniform germination. Moreover, primed onion and leek seeds maintained viability after one year when stored at $10^{\circ} \mathrm{C}$ (Drew et al., 1997). Similar results have been reported in the case of tomato, asparagus and canola (Argerich et al., 1989; Owen and Pill, 1994; Basra et al., 2003). Many researchers have studied effect of seed priming on enhancement of germination, morphological characters, yield, etc. (Thejeshwini et al., 2019; Muruli et al., 2016; Saranya, 2017; Patil and Manjare, 2013; Arin et al., 2011; Selvarani and Umarani, 2011; Nego et al., 2015).

Seed priming (pre-sowing hydration treatments of seeds) is widely used for enabling better crop establishment (Taylor et al., 1998). Priming is a process in which seeds are imbibed in either water or osmotic solution or a combination of solid matrix carrier and water in specific proportions followed by drying before radicle emergence. In several studies, an increase in the nuclear DNA contents of radicle meristem cells from the G1 to the S or G2 phases of the cell cycle was noticed. The recorded effects of priming treatments on the storability of seeds are contradictory. The advancement of the germination process during priming continuously consumes stored substances and consequently may shorten seed longevity. However, the repair of DNA damage will increase longevity (Osborne, 1983). The results obtained so far are few, limited, contrasting because of the variability of the response to treatments of cultivars and even seed lots (Bradford, 1986) which require a careful choice of the compounds to proper standardization of the seed priming method and methodology for individual crops is the most critical determinant of success of the seed priming treatment.

In storage, the viability and vigour of the seeds not only vary from genera to genera and variety to variety, but is also regulated by many physicochemical factors like moisture content, atmospheric relative humidity, temperature, initial seed quality, physical and chemical composition of seed, gaseous exchange, storage structure, packaging materials etc. (Doijode, 1988). It will be of immense use to seed industry and farming community that how best the seeds can be stored by treating the seeds with chemicals and inert matter at relatively low cost under ambient storage and refrigerated conditions, with minimum quantitative and qualitative losses. As the quality, seed plays an important role in obtaining higher returns, as it is expected to perform well under any given environmental conditions.

Keeping in view the above facts, the present study was conducted with the objective of determining the most appropriate seed priming treatment and its physiological effects in differentially aged onion seeds.

\section{Materials and methods}

\section{Experimental layout}

The freshly harvested seed of three onion cultivars viz., Hisar-2 (V1), Hisar Onion-3 (V2) and Hisar Onion-4 (V3) were brought to the laboratory and stored in cloth bags under room temperature conditions $\left(27 \pm 1{ }^{\circ} \mathrm{C}\right.$, relative humidity $\left.(\mathrm{RH}) 54 \pm 3 \%\right)$ with seed moisture $7-8 \%$. The seed lots of each of the three varieties were stored under ambient conditions in the laboratory of Seed Science and Technology, Haryana Agricultural University), Hisar, India This seed was used for further studies according 
to different years of natural seed ageing. These varieties were selected based on their extensive cultivation and popularity among Haryana farmers. Details of the experimental material are provided in Table 1.

Table 1. Differentially aged seedlot during the two years of study

\begin{tabular}{c|c|c|c}
\hline Year of study & Lots & Year of production & Age of seed lot/seed age \\
\hline \multirow{3}{*}{2013} & A & 2013 & Fresh \\
& B & 2012 & 1 years old \\
& C & 2011 & 2 years old \\
\hline \multirow{3}{*}{2014} & A & 2014 & Fresh \\
& B & 2013 & 1 year old \\
& C & 2012 & 2 years old \\
& D & 2011 & 3 years old \\
\hline
\end{tabular}

\section{Treatments}

Six seed priming treatments were compared with untreated control. The treatments are detailed in Table 2 .

Table 2. Details of priming treatments under study

\begin{tabular}{|c|c|}
\hline $\begin{array}{l}\text { Hydro-priming followed by dry dressing } \\
\text { with Thiram }(2 \mathrm{~g} / \mathrm{kg})\end{array}$ & $\begin{array}{l}\text { Hydration with distilled water and followed by dry dressing } \\
\text { of seeds by thiram fungicides ( } 2 \mathrm{~g} / \mathrm{kg} \text { seed })\end{array}$ \\
\hline Hydration with $\mathrm{GA}_{3}(50 \mathrm{ppm})$ & $\begin{array}{c}50 \mathrm{mg} \text { of gibberellic acid }\left(\mathrm{GA}_{3}\right) \text { was dissolved in } 2 \mathrm{~L} \text { of } \\
\text { water to make solution of concentration of } 50 \mathrm{ppm} \text {. One to } \\
\text { three drops of acetone were also added as } \mathrm{GA}_{3} \text { cannot } \\
\text { dissolve in distilled water }\end{array}$ \\
\hline Hydration with $\mathrm{KNO}_{3}(0.5 \%$ solution $)$ & $\begin{array}{c}5 \mathrm{~g} \text { of potassium nitrate }\left(\mathrm{KNO}_{3}\right) \text { was dissolved in } 1 \mathrm{~L} \text { of } \\
\text { distilled water }\end{array}$ \\
\hline Hydration with $\mathrm{KH}_{2} \mathrm{PO}_{4}(0.5 \%$ solution $)$ & $\begin{array}{l}5 \mathrm{~g} \text { of potassium dihydrogen phosphate }\left(\mathrm{KH}_{2} \mathrm{PO}_{4}\right) \text { was } \\
\text { dissolved in } 1 \mathrm{~L} \text { of distilled water }\end{array}$ \\
\hline Biofertilizer (Azotobacter) & $\begin{array}{c}\text { Seeds were first treated with } 2 \% \text { jaggary solution and then } \\
\text { with Azotobacter strain HT-57. The strain was taken from } \\
\text { the biofertilizers unit of CCS HAU, Hisar }\end{array}$ \\
\hline
\end{tabular}

The seed of each lot was soaked in a sufficient amount of solution for $16 \mathrm{~h}$ in each treatment. Then the seed was dried in the shade at $20^{\circ} \mathrm{C}$ to attain the initial seed weight to maintain original or near to safe moisture content.

\section{Observations}

\section{Germination and seed viability determination}

Germination assays were determined according to the procedure described by International rules for seed testing (ISTA, 2015) by placing seeds in Petri plates for germination at $20-22{ }^{\circ} \mathrm{C}$ and $90 \pm 2 \% \mathrm{RH}$ (100 sterilized seeds per Petri plate in four replicates) in a germination chamber. Germination (\%) was scored at radicle growth of $2 \mathrm{~mm}$, or more and counting of normal and abnormal seedlings was started on the $5^{\text {th }}$ day 
and continued up to the $20^{\text {th }}$ day (final count) followed by calculation of germination percentage. After the germination test, seedling length, dry seedling weight and seed vigour index were measured and calculated as per the standard procedure. Seedling length $(\mathrm{cm})$ was measured from 20 randomly selected healthy seedlings at the time of final count of germination. These selected seedlings were then kept in a hot air oven at $60{ }^{\circ} \mathrm{C}$ for $48 \mathrm{~h}$ for the recording of seedling dry weight $(\mathrm{mg})$. Based on the seed germination, seedling length and seedling dry weight data, seed vigour index-I (SV-I) and seed vigour index-II (SVI-II) were calculated (Abdul Baki and Anderson, 1972). To evaluate the viability, 25 seeds were soaked in $50 \mathrm{ml}$ water and kept in the incubator at $30 \pm 1{ }^{\circ} \mathrm{C}$ (in three replicates) for $24 \mathrm{~h}$. After incubation, seeds were cut longitudinally and maintained in $1 \%$ staining solution of 2,3,5-triphenyl tetrazolium chloride (TTC) for $4 \mathrm{~h}$ at $38 \pm 1{ }^{\circ} \mathrm{C}$ under dark conditions (Moore, 1973). During the staining period, only viable part of the seed is converted into red colour due to the formation of triphenyl formazon from TTC solution.

\section{Electrical conductivity test (EC)}

The electrical conductivity of seed leachates was measured for seeds of different age. Fifty seeds were soaked in $75 \mathrm{ml}$ deionised water and incubated at $25^{\circ} \mathrm{C}$ for $24 \mathrm{~h}$. Seed leachates were collected, and conductivity $(\mathrm{dS} / \mathrm{cm} / \mathrm{seed})$ was recorded by using digital conductivity meter (Model 304, Systronics, Ahmedabad, India) along with deionised water as a control (Dadlani and Aggarwal, 1987).

\section{Field parameters}

\section{Seedling emergence index (SEI)}

The number of seedlings emerged under field conditions were counted daily from $1^{\text {st }}$ day to $20^{\text {th }}$ day, and the seedling emergence index was calculated as described by (Maguire, 1962).

$$
\text { SEI }=\frac{\text { No. of seedlings emerged on the first day }}{\text { Day of the first count (1st) }}+\cdots+\frac{\text { No. of seedlings emerged on last day }}{\text { Day of the last count (20th) }}
$$

\section{Seedling establishment (\%)}

Seedling establishment was estimated under field conditions by including the total number of seedlings after emergence or when there was no further addition to the total emergence.

\section{Statistical analyses}

The statistical analysis was carried out for each observed character under the study using MS-Excel and SPSS Statistics 20. The means of the treatments were compared using Duncan's Multiple Range Test (DMRT). Besides, the linear regressions were determined with the help of data analysis tool pack in MS Excel.

\section{Experimental results}

Results of the study showed that the effect of priming, seed age and their interaction were significant at $\mathrm{p}<0.05$ for all the seed quality parameters studied. Therefore, the seed lots of different ages were analysed separately for all the parameters. The 
laboratory parameters study was laid in completely randomized design CRD (Table 3), and field parameters were laid in randomized block design RBD (Table 4). During the second year of study, an additional seed lot of three-year-old seed was also studied.

Table 3. Analysis of variance for seed quality characteristics of onion seed as affected by different priming treatments

\begin{tabular}{c|c|c|c|c|c|c|c|c}
\hline $\begin{array}{c}\text { Source of } \\
\text { variation }\end{array}$ & df & Germination & SL & SDW & SVI-I & SVI-II & Viability & EC \\
\hline Seed lot (L) & 2 & $20,143.92^{*}$ & $432.81^{*}$ & $37.97 *$ & $16,315,106.15^{*}$ & $859,446.45^{*}$ & $20,447.85^{*}$ & $6.42^{*}$ \\
Priming (P) & 5 & $259.64 *$ & $126.96^{*}$ & $0.27 *$ & $846,361.19^{*}$ & $8,555.79 *$ & $111.45^{*}$ & $0.21^{*}$ \\
L*P & 10 & $13.03^{*}$ & $10.66^{*}$ & $0.02 * *$ & $99,516.17 *$ & $747.50 *$ & $3.51^{*}$ & $0.16^{*}$ \\
Error & 108 & 1.99 & 0.69 & 0.01 & $6,374.95$ & 139.23 & 1.40 & 0.002 \\
\hline
\end{tabular}

*Significant at $1 \%$ level of significance; **Significant at $5 \%$ level of significance; SL- seedling length; SDW- seedling dry weight; SVI-I- Seed vigour index-I; SVI-II- seed vigour index-II; EC- electrical conductivity

Table 4. Analysis of variance for field parameters of onion seed as affected by different priming treatments

\begin{tabular}{c|c|c|c}
\hline Source of variation & df & SEI & SE \\
\hline Seed age $(\mathrm{L})$ & 2 & $267.71^{*}$ & $18,413.84^{*}$ \\
Priming $(\mathrm{P})$ & 5 & $6.05^{*}$ & $101.54^{*}$ \\
$\mathrm{~L} * \mathrm{P}$ & 10 & $0.20^{* *}$ & $17.57^{*}$ \\
Error & 105 & 0.13 & 0.79 \\
\hline
\end{tabular}

*Significant at $1 \%$ level of significance; **Significant at $5 \%$ level of significance; SEI- seedling emergence index; SE- seedling establishment

Seed priming has significant influence $(\mathrm{p}<0.05)$ on the different traits of onion seed. Among the different seed priming treatments, hydration with $\mathrm{GA}_{3}(50 \mathrm{ppm})$ was most effective in enhancing different traits followed by treatment with biofertilizer Azotobacter. Other treatments in declining order of seed quality are, hydro priming followed by dry dressing with Thiram $(2 \mathrm{~g} / \mathrm{kg})$, hydration with $\mathrm{KH}_{2} \mathrm{PO}_{4}(0.5 \%)$ and hydration with $\mathrm{KNO}_{3}(0.5 \%)$. Priming of seeds with various treatments was found competent to improve the quality in fresh and marginal seed lots. Out of the differentially aged seed lots, fresh seed performed the best, and the seed quality tends to decline with the ageing of the seed. Fresh seed lot was characterized by a high number of germinating seeds, exceeding $80 \%$ even in unprimed seed (Table 5). GA 3 emerged as the most effective priming treatment as it registered $11.23 \%$ increase in germination over control. After a year of storage, germination under different priming treatments dropped by 12.45 (Azotobacter), $13.11\left(\mathrm{GA}_{3}\right), 17.55$ (Thiram), $20.1\left(\mathrm{KH}_{2} \mathrm{PO}_{4}\right)$ and $20.45 \%\left(\mathrm{KNO}_{3}\right)$, while unprimed seed recorded a reduction of $21.45 \%$. A decline in germination in all the treatments was above $40 \%$ after three years of storage when compared with germination after two years of storage. The decrease in germination after three years of storage was below $10 \%$. A similar trend was observed in the case of seed viability, where there was a steep decline after one year of storage (Table 5). 
Table 5. Germination (\%) and viability (\%) of differentially aged onion seed lots under different priming treatments

\begin{tabular}{c|c|c|c|c|c|c|c|c}
\hline \multirow{2}{*}{$\begin{array}{c}\text { Priming } \\
\text { treatment }\end{array}$} & \multicolumn{4}{|c|}{ Germination (\%) } & \multicolumn{4}{c}{ Viability (\%) } \\
\cline { 2 - 9 } & Lot1 & Lot2 & Lot3 & Lot4 & Lot1 & Lot2 & Lot3 & Lot4 \\
\hline Thiram & $88.43 \mathrm{~b}$ & $70.88 \mathrm{c}$ & $27.20 \mathrm{a}$ & $20.11 \mathrm{a}$ & $88.41 \mathrm{a}$ & $67.43 \mathrm{~b}$ & $22.26 \mathrm{~b}$ & $19.44 \mathrm{~b}$ \\
$\mathrm{GA}_{3}$ & $91.32 \mathrm{a}$ & $78.21 \mathrm{a}$ & $27.16 \mathrm{a}$ & $20.67 \mathrm{a}$ & $89.41 \mathrm{a}$ & $70.71 \mathrm{a}$ & $24.98 \mathrm{a}$ & $22.89 \mathrm{a}$ \\
$\mathrm{KNO}_{3}$ & $84.88 \mathrm{c}$ & $64.44 \mathrm{~d}$ & $21.73 \mathrm{~b}$ & $13.33 \mathrm{~b}$ & $84.26 \mathrm{c}$ & $63.05 \mathrm{c}$ & $18.37 \mathrm{c}$ & $14.78 \mathrm{c}$ \\
$\mathrm{KH}_{2} \mathrm{PO}_{4}$ & $85.43 \mathrm{c}$ & $65.33 \mathrm{~d}$ & $22.05 \mathrm{~b}$ & $14.33 \mathrm{~b}$ & $83.26 \mathrm{c}$ & $64.16 \mathrm{c}$ & $19.01 \mathrm{c}$ & $15.67 \mathrm{c}$ \\
Azotobacter & $88.88 \mathrm{~b}$ & $76.43 \mathrm{~b}$ & $26.10 \mathrm{a}$ & $18.89 \mathrm{a}$ & $86.21 \mathrm{~b}$ & $68.18 \mathrm{~b}$ & $24.76 \mathrm{a}$ & $21.89 \mathrm{ab}$ \\
Control & $82.10 \mathrm{~d}$ & $60.53 \mathrm{e}$ & $17.47 \mathrm{c}$ & $8.56 \mathrm{c}$ & $83.02 \mathrm{c}$ & $61.33 \mathrm{~d}$ & $17.89 \mathrm{c}$ & $14.11 \mathrm{c}$ \\
\hline
\end{tabular}

Means under same parameter sharing letters are not significantly different at $\alpha=0.05$; Lot 1 : Fresh seed; Lot2: One-year old seed; Lot3: Two-year old seed; Lot4: Three-year-old seed

Seed priming with $\mathrm{GA}_{3}$ in fresh seed was the best combination followed by priming with Thiram. More than $70.71 \% \mathrm{GA}_{3}$ primed seed was viable in the one-year-old seed lot. Viability of seed was below $25 \%$ in the primed and non-primed seed of two and three-year-old seed lot. A gradual decline in seedling length $(\mathrm{cm})$ and seedling dry weight $(\mathrm{mg})$ was observed in all the priming treatments with the progression of storage period (Table 6). In all of the aged seed lots, priming with $\mathrm{GA}_{3}$ improved both seedling characteristics over other priming treatments in differentially aged seed lots. Seed vigour index- I (SVI-I) was highest in $\mathrm{GA}_{3}$ primed seed in case of fresh, one year old and three-year-old seed lots (Table 7). While SVI-I was highest in Thiram primed seed that has been stored for two years.

Table 6. Seedling length $(\mathrm{cm})$ and dry weight $(\mathrm{mg})$ of differentially aged onion seed lots under different priming treatments

\begin{tabular}{c|c|c|c|c|c|c|c|c}
\hline \multirow{2}{*}{$\begin{array}{c}\text { Priming } \\
\text { treatment }\end{array}$} & \multicolumn{4}{|c|}{ Seedling length $(\mathrm{cm})$} & \multicolumn{4}{c}{ Seedling dry weight (mg) } \\
\cline { 2 - 9 } & Lot1 & Lot2 & Lot3 & Lot4 & Lot1 & Lot2 & Lot3 & Lot4 \\
\hline Thiram & $16.45 \mathrm{c}$ & $14.16 \mathrm{~b}$ & $12.47 \mathrm{~b}$ & $10.98 \mathrm{~b}$ & $3.57 \mathrm{bc}$ & $2.76 \mathrm{ab}$ & $1.77 \mathrm{bc}$ & $0.95 \mathrm{ab}$ \\
$\mathrm{GA}_{3}$ & $18.98 \mathrm{a}$ & $16.70 \mathrm{a}$ & $14.53 \mathrm{a}$ & $13.18 \mathrm{a}$ & $3.75 \mathrm{a}$ & $2.79 \mathrm{a}$ & $1.94 \mathrm{a}$ & $1.12 \mathrm{a}$ \\
$\mathrm{KNO}_{3}$ & $14.34 \mathrm{~d}$ & $10.82 \mathrm{~d}$ & $8.75 \mathrm{~d}$ & $6.46 \mathrm{~cd}$ & $3.49 \mathrm{bc}$ & $2.49 \mathrm{c}$ & $1.71 \mathrm{c}$ & $0.98 \mathrm{ab}$ \\
$\mathrm{KH}_{2} \mathrm{PO}_{4}$ & $16.12 \mathrm{c}$ & $11.61 \mathrm{c}$ & $10.01 \mathrm{c}$ & $8.08 \mathrm{c}$ & $3.49 \mathrm{bc}$ & $2.71 \mathrm{~b}$ & $1.72 \mathrm{c}$ & $0.90 \mathrm{c}$ \\
Azotobacter & $17.63 \mathrm{~b}$ & $9.94 \mathrm{e}$ & $8.34 \mathrm{~d}$ & $11.19 \mathrm{~b}$ & $3.62 \mathrm{ab}$ & $2.73 \mathrm{ab}$ & $1.86 \mathrm{ab}$ & $1.00 \mathrm{ab}$ \\
Control & $13.78 \mathrm{~d}$ & $9.26 \mathrm{f}$ & $8.17 \mathrm{~d}$ & $5.91 \mathrm{~d}$ & $3.43 \mathrm{c}$ & $2.53 \mathrm{c}$ & $1.70 \mathrm{c}$ & $0.89 \mathrm{c}$ \\
\hline
\end{tabular}

Means under same parameter sharing letters are not significantly different at $\alpha=0.05$; Lot1: Fresh seed; Lot2: One-year-old seed; Lot3: Two-year-old seed; Lot4: Three-year-old seed

On the other hand, seed vigour index- II (SVI-II) was highest in Azotobacter primed two-year-old seed (Table 7). GA 3 priming recorded highest SVI-II in other aged seed lots. Electrical conductivity (EC) of $\mathrm{GA}_{3}$ primed seed was lowest among the all priming treatments in the four seed lots studied (Table 8). This was followed by priming treatments of Azotobacter and Thiram, while the oldest aged seed had the highest EC values. The field parameters, i.e., seedling emergence index (SEI) and seedling establishment (SE) were also high in the fresh and one-year-old seed lot and followed a 
steep decline in two and three-year-old seed lot (Table 9). $\mathrm{GA}_{3}$ primed seed also performed best in case of the field parameters followed by treatment with Azotobacter.

Table 7. Seed vigour index-I (SVI-I) and seed vigour index-II (SVI-II) of differentially aged onion seed lots under different priming treatments

\begin{tabular}{c|c|c|c|c|c|c|c|c}
\hline \multirow{2}{*}{$\begin{array}{c}\text { Priming } \\
\text { treatment }\end{array}$} & \multicolumn{4}{|c|}{ Seed vigour index- I } & \multicolumn{4}{c}{ Seed vigour index- II } \\
\cline { 2 - 9 } & Lot1 & Lot2 & Lot3 & Lot4 & Lot1 & Lot2 & Lot3 & Lot4 \\
\hline Thiram & $1459.38 \mathrm{bc}$ & $1001.14 \mathrm{~b}$ & $342.31 \mathrm{~b}$ & $224.47 \mathrm{~b}$ & $316.54 \mathrm{bc}$ & $196.07 \mathrm{c}$ & $48.47 \mathrm{a}$ & $19.51 \mathrm{~b}$ \\
$\mathrm{GA}_{3}$ & $1738.16 \mathrm{a}$ & $1302.87 \mathrm{a}$ & $398.71 \mathrm{a}$ & $276.76 \mathrm{a}$ & $343.33 \mathrm{a}$ & $219.09 \mathrm{a}$ & $53.01 \mathrm{a}$ & $23.25 \mathrm{a}$ \\
$\mathrm{KNO}_{3}$ & $1219.68 \mathrm{~d}$ & $694.64 \mathrm{~d}$ & $191.20 \mathrm{c}$ & $86.40 \mathrm{~d}$ & $296.96 \mathrm{~cd}$ & $160.93 \mathrm{e}$ & $36.94 \mathrm{~b}$ & $13.03 \mathrm{c}$ \\
$\mathrm{KH}_{2} \mathrm{PO}$ & $1380.20 \mathrm{c}$ & $756.47 \mathrm{c}$ & $222.86 \mathrm{c}$ & $118.62 \mathrm{c}$ & $298.60 \mathrm{~cd}$ & $177.32 \mathrm{~d}$ & $38.29 \mathrm{~b}$ & $13.12 \mathrm{c}$ \\
Azotobacter & $1570.35 \mathrm{~b}$ & $743.70 \mathrm{~cd}$ & $203.20 \mathrm{c}$ & $214.69 \mathrm{~b}$ & $322.21 \mathrm{~b}$ & $209.04 \mathrm{~b}$ & $48.78 \mathrm{a}$ & $19.06 \mathrm{~b}$ \\
Control & $1132.59 \mathrm{~d}$ & $59.96 \mathrm{e}$ & $146.28 \mathrm{~d}$ & $52.28 \mathrm{e}$ & $281.77 \mathrm{~d}$ & $153.52 \mathrm{f}$ & $29.84 \mathrm{c}$ & $7.95 \mathrm{~d}$ \\
\hline
\end{tabular}

Means under same parameter sharing letters are not significantly different at $\alpha=0.05$; Lot1: Fresh seed; Lot2: One-year old seed; Lot3: Two-year-old seed; Lot4: Three-year-old seed

Table 8. Electrical conductivity $(\mathrm{dS} / \mathrm{cm} / \mathrm{see})$ of differentially aged onion seed lots under different priming treatments

\begin{tabular}{c|c|c|c|c}
\hline \multirow{2}{*}{ Priming treatment } & \multicolumn{4}{|c}{ Electrical conductivity (dS/cm/seed) } \\
\cline { 2 - 5 } & Lot1 & Lot2 & Lot3 & Lot4 \\
\hline Thiram & $0.256 \mathrm{bc}$ & $0.721 \mathrm{~cd}$ & $0.830 \mathrm{c}$ & $1.34 \mathrm{bc}$ \\
$\mathrm{GA}_{3}$ & $0.246 \mathrm{c}$ & $0.714 \mathrm{~d}$ & $0.798 \mathrm{c}$ & $1.29 \mathrm{c}$ \\
$\mathrm{KNO}_{3}$ & $0.276 \mathrm{a}$ & $0.732 \mathrm{bc}$ & $0.865 \mathrm{c}$ & $1.39 \mathrm{bc}$ \\
$\mathrm{KH}_{2} \mathrm{PO}_{4}$ & $0.265 \mathrm{ab}$ & $0.739 \mathrm{~b}$ & $1.08 \mathrm{~b}$ & $1.60 \mathrm{~b}$ \\
Azotobacter & $0.256 \mathrm{bc}$ & $0.714 \mathrm{~d}$ & $0.862 \mathrm{c}$ & $1.35 \mathrm{bc}$ \\
Control & $0.278 \mathrm{a}$ & $0.757 \mathrm{a}$ & $1.47 \mathrm{a}$ & $2.02 \mathrm{a}$ \\
\hline
\end{tabular}

Means under same parameter sharing letters are not significantly different at $\alpha=0.05$; Lot1: Fresh seed; Lot2: One-year-old seed; Lot3: Two-year-old seed; Lot4: Three-year-old seed

Table 9. Seedling emergence index and seedling establishment (\%) of differentially aged onion seed lots under different priming treatments

\begin{tabular}{c|c|c|c|c|c|c|c|c}
\hline \multirow{2}{*}{$\begin{array}{c}\text { Priming } \\
\text { treatment }\end{array}$} & \multicolumn{3}{|c|}{ Seedling emergence index } & \multicolumn{4}{c}{ Seedling establishment (\%) } \\
\cline { 2 - 8 } & Lot1 & Lot2 & Lot3 & Lot4 & Lot1 & Lot2 & Lot3 & Lot4 \\
\hline Thiram & $6.89 \mathrm{abc}$ & $5.66 \mathrm{c}$ & $2.39 \mathrm{c}$ & $1.98 \mathrm{c}$ & $68.39 \mathrm{bc}$ & $63.16 \mathrm{~b}$ & $11.61 \mathrm{bc}$ & $5.94 \mathrm{ab}$ \\
$\mathrm{GA}_{3}$ & $7.39 \mathrm{a}$ & $6.31 \mathrm{a}$ & $3.14 \mathrm{a}$ & $2.75 \mathrm{a}$ & $71.28 \mathrm{a}$ & $65.93 \mathrm{a}$ & $12.78 \mathrm{a}$ & $6.39 \mathrm{a}$ \\
$\mathrm{KNO}_{3}$ & $6.64 \mathrm{bc}$ & $5.61 \mathrm{c}$ & $2.10 \mathrm{~d}$ & $1.71 \mathrm{~cd}$ & $66.50 \mathrm{~cd}$ & $58.49 \mathrm{~d}$ & $10.01 \mathrm{~d}$ & $4.28 \mathrm{c}$ \\
$\mathrm{KH}_{2} \mathrm{PO}_{4}$ & $6.66 \mathrm{bc}$ & $5.66 \mathrm{c}$ & $1.91 \mathrm{e}$ & $1.46 \mathrm{~d}$ & $65.61 \mathrm{~d}$ & $60.38 \mathrm{c}$ & $10.97 \mathrm{c}$ & $5.28 \mathrm{~b}$ \\
Azotobacter & $7.12 \mathrm{ab}$ & $5.88 \mathrm{~b}$ & $2.74 \mathrm{~b}$ & $2.34 \mathrm{~b}$ & $69.06 \mathrm{~b}$ & $65.49 \mathrm{a}$ & $12.04 \mathrm{~b}$ & $5.94 \mathrm{ab}$ \\
Control & $6.27 \mathrm{c}$ & $4.75 \mathrm{~d}$ & $1.38 \mathrm{f}$ & $0.95 \mathrm{e}$ & $64.50 \mathrm{~d}$ & $49.05 \mathrm{e}$ & $9.38 \mathrm{~d}$ & $3.72 \mathrm{c}$ \\
\hline
\end{tabular}

Means under same parameter sharing letters are not significantly different at $\alpha=0.05$; Lot1: Fresh seed; Lot2: One-year-old seed; Lot3: Two-year-old seed; Lot4: Three-year-old seed 
Based on the effectiveness for enhancement of germination, vigour and storage potential, the best priming treatment is $\mathrm{GA}_{3} @ 50 \mathrm{ppm}$ followed by Biofertilizer Aztobacter. While the least effective treatment was $\mathrm{KNO}_{3}$. Priming of the seeds with various treatments was found competent to improve the seed quality in fresh as well as marginal (one-year-old) and sub-marginal (two-year-old) seed age. No doubt performance of fresh seed was found better over all the other lots but, the improvement was comparatively more in marginal seed age, i.e., one-year-old seed lot (Lot1) because in this lot seed germination achieved up to $70 \%$ as per Indian minimum seed certification standards (IMSCS) standards.

Linear regression analysis revealed that germination and SE exhibited significant positive relationship $(\mathrm{p}<0.05)$ in one-year-old seed lot, where germination explained $81 \%$ variation in SE (Fig. 1). Successful SE depends on several factors and ability of seeds to germinate is one of them. Present studies reveal that higher germination capacity under laboratory conditions is quite apparent through better establishment of seedlings under field conditions. These two parameters had a high positive correlation $(\mathrm{r}=0.90)$, which indicates that priming in the one-year-old seed can result in good performance in field conditions. Similarly, both the vigour indices, i.e., SVI-I $(\mathrm{p}<0.01)$ and SVI-II $(\mathrm{p}<0.05)$ also had a positive association with SEI in one-yearold seed lot. SVI-I and SVI-II explained 89 and $73 \%$ variation in SEI, respectively (Fig. 2). Correlation of SVI-I and SVI-II with SEI had high positive values of 0.94 and 0.85 , respectively. Vigour indices are based on germination, seedling length and seedling dry weight, and high values of these indices indicate fast-growing seedlings with good quality characteristics which are ultimately reflected in SEI. Fast-growing and healthy seedlings (which are a basis for vigour indices) lead to the higher values of SEI. Overall, it could be said that priming of onion seed stored for one year has good performance under heterogeneous field conditions leading to a good plant stand.

\section{Discussion}

Seed priming was identified to improve the germination and seedling establishment in some of the critical field crops like soybean, wheat, maize, sunflower and sugarbeet (Singh, 1995; Khajeh-Hosseini et al., 2003; Sdeghian and Yavari, 2004). The improved performance and quality of seed after is due to several processes like DNA repair, activation of enzymes and endosperm weakening in primed seeds (Osborne, 1983; Dell'Aquilla et al., 1998; Moosavi et al., 2009). Also, priming enhances antioxidant activity in the seeds, which results in reduced lipid peroxidation, improves seed quality (Hsu et al., 2003; Chiu et al., 2006). Davison and Bray (1991) have observed some changes in the protein pattern in the primed seeds. Vigorous crops grown from primed seeds were able to capture more nitrogen than plants grown from non-primed seeds, thus utilising nitrogen before leaching or volatilization losses (Byrum and Copland, 1995). Ramadevi and Gopalkrishan (2001) are of the view that enhanced hydration of all seed parts leading to reduced damage to the embryonic axis could be the reason behind the increased speed of emergence and seedling establishment. Toxic effect of potassium salts on the germinating seeds is the reason behind $\mathrm{KNO}_{3}$ being the least effective treatment. Toxic effect of KCL has been reported by some workers where it has a negative effect on germinating embryos which leads to a reduction in germination and seedling death (Giri and Schillinger, 2003; Yari et al., 2011). 


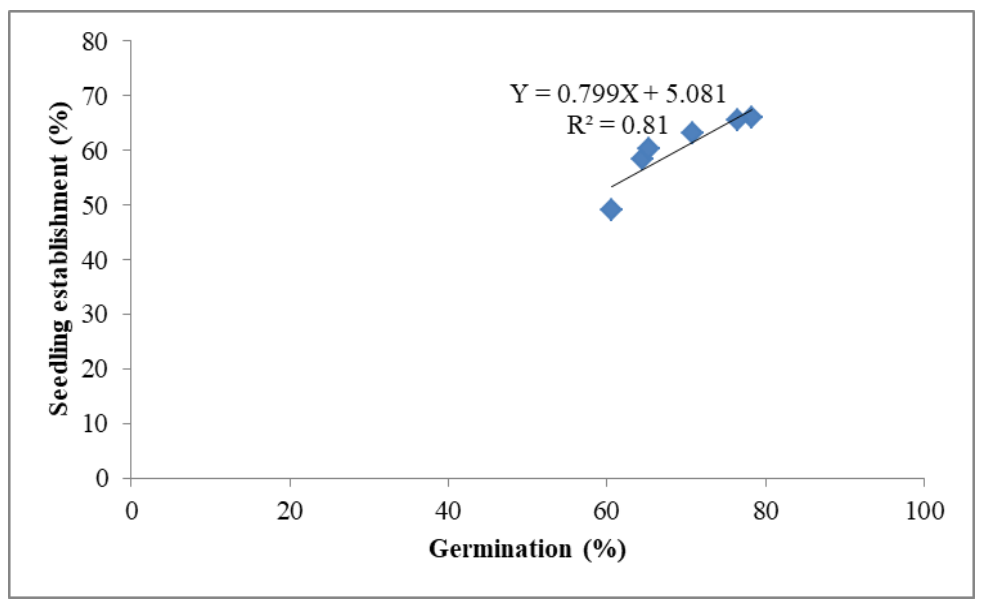

Figure 1. Relationship between seedling establishment (\%) and germination (\%) in one-yearold seed

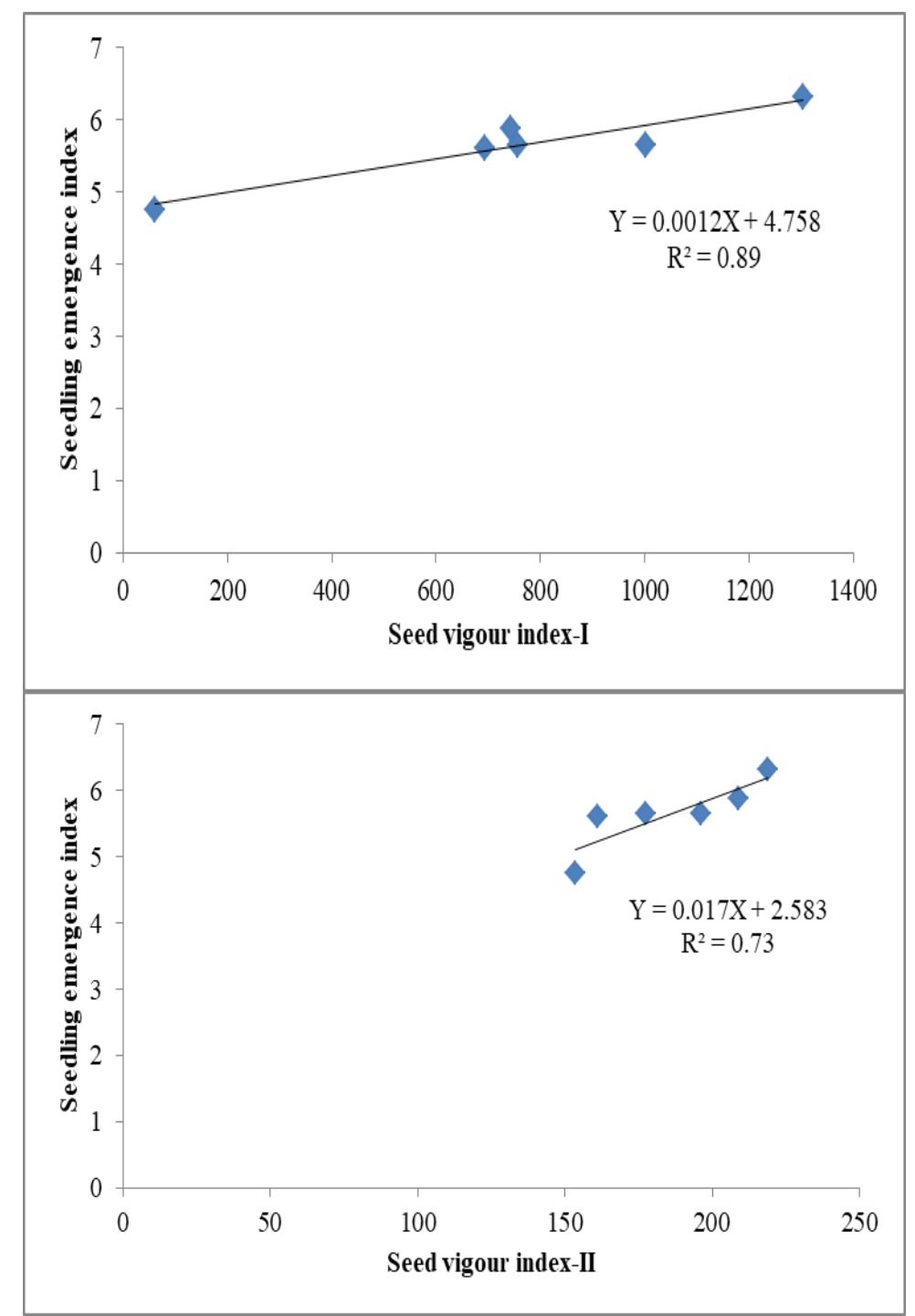

Figure 2. Relationship between seedling emergence index (SEI) and seed vigour index-I (SVI-I) and seed vigour index-II (SVI-II) in one-year-old seed 
Gibberellic Acid $\left(\mathrm{GA}_{3}\right)$ is an essential growth regulator, which aids in breaking seed dormancy, promoting germination, internodal length, growth of hypocotyl and cell division in the cambial zone and enlargement of leaf size. $\mathrm{GA}_{3}$ degrades cells surrounding the radicle by stimulating hydrolytic enzymes, which ultimately speeds germination (Rood et al., 1990). $\mathrm{GA}_{3}$ also plays a vital role in the mobilization of endosperm reserves during germination of seeds (Weiss and Ori, 2007). During the germination process, $\mathrm{GA}_{3}$ is released from an embryo, which activates genes responsible for alpha-amylase mRNA transcription (Taiz and Zeiger, 1991). Exogenous application of $\mathrm{GA}_{3}$ might lead to activation of such genes in seeds, thus improving germination. Increased vigour characteristics elevated peroxide scavenging enzymes activities and decline in lipid peroxidation some of the possible reasons behind enhanced seed germination. Higher metabolic activity in primed seeds causes efficient food mobilization during early hours of germination, which leads to increased shoot and root lengths (Brar et al., 2019).

Consequently, it results in higher seedling dry weight (Bailly et al., 2002; Jett et al., 1996). Priming of fresh and aged onion seed with $\mathrm{GA}_{3}(50 \mathrm{ppm})$ resulted in favourbale impact on the germination ability and seed vigour. Also the aged seed was more responsive to priming as compared to the fresh seed (Muruli et al., 2016). Yarnia et al. (2012) determined the effect of hormonal treatments i.e., IAA, $\mathrm{GA}_{3}$ and kinetin on germination and seedling growth of onion. Of these priming treatments $\mathrm{GA}_{3}$ and IAA led to improved attributes such as germination, seedling length, root length, seedling dry weight etc. Helaly et al. (2016) also reported highest germination, seed yield and weight of thousand seeds in $\mathrm{GA}_{3}(1000 \mathrm{ppm})$ primed onion seeds. In case of shallots also $\mathrm{GA}_{3}$ priming significantly enhances the germination, speed of germination, seedling vigour and rate of seedling emergence (Agung and Diara, 2017).

$\mathrm{GA}_{3}$ priming was followed by bio-priming with Azotobacter, which is known to promote plant growth through indole-3-acetic acid (IAA) production and nitrogen fixation (Hafeez et al., 2004). Azotobacter inoculations are known to produce $\mathrm{GA}_{3}$, IAA and cytokinins (Barea and Brown, 1974), which enhances seedling development and plant growth (Brown, 1982). Bacteria produce plant growth regulators which alter morphology and metabolism of the plant, yields more extended root systems and improves absorption of water and minerals (Bashan et al., 2004; Lai et al., 2008; Fibach-Paldi et al., 2012). Azotobacter enhances germination in rice and cotton by the synthesis of growth promoters and antifungal antibiotic production, which ensure seed safety during germination (Shende et al., 1977). Inoculation with Azotobacter increases shoot, and root length in maize and sorghum and pre-soaking of seed improves germination and seedling establishment (Ahmed et al., 1998). Bio-agents are also more effective as compared to synthetic chemicals as they improve seed quality characteristics while providing tolerance to other toxic agents. Brar et al. (2015) reported improved seed quality characteristics in tomato with the supply of biofertilizers like Azotobacter. Treatment with biofertilizers also enhanced the seed yield and improved the fertility status of the soil by nitrogen fixation.

Lower EC for primed seed may be due to improved plasma membrane structure as a result of slow hydration in the priming treatments (McDonald, 1980). Kumar (2004) reported that onion seeds treated with $\mathrm{GA}_{3}$ recorded the maximum decline in seed leachates in comparison to control. Improvement of germination at high levels of ageing was not achieved through priming as the irreversible damage could not be repaired (Butler et al., 2009). During the programmed cell death (PCD), catalase rate and 
sensitivity reduce, which indicates that the ageing causes PCD and subsequent the reduction of seed viability.

\section{Conclusion}

It is concluded that the standard germination, vigour indices and EC tests could be used as reliable predictors of seed quality because of easiness, quickness and accuracy in their execution. Further, various seed priming treatments can be used for enhancing seed quality of marginal seed lot. $\mathrm{GA}_{3}(50 \mathrm{ppm})$ was found to be best priming treatment for improving the seed quality followed by biofertilizer (Azotobacter), hydro priming and dry dressing with Thiram (2 $\mathrm{g} / \mathrm{kg})$, KH 2 PO $4(0.5 \%)$ and $\mathrm{KNO} 3(0.5 \%)$, respectively. Overall, the priming technology was found useful and beneficial for enhancing the physiological, biochemical and storage potential of onion seed. Indeed, in the case of these onion varieties, we recommend the priming treatment for getting a bumper harvest.

\section{REFERENCES}

[1] Abdul-Baki, A. A., Anderson, J. D. (1972): Physiological and Biochemical Deterioration of Seeds. - In: Kozlowski, T. T. (ed.). Seed Biology. Academic Press, New York, pp. 283-315.

[2] Agung, I. G. A. M. S., Diara, I. W. (2017): Pre-sowing treatment enhanced germination and vigour of true shallot (Allium cepa var. aggregatum) seeds. - International Journal of Environment Agriculture and Biotechnology 2: 3262-67.

[3] Ahmed, S., Anwar, M., Ullah, H. (1998): Wheat seed presoaking for germination. Journal of Agronomy and Crop Science 181: 125-27.

[4] Argerich, C. A., Bradford, K. J., Tarquis, A. M. (1989): The effects of priming and ageing on resistance to deterioration of tomato seeds. - Journal of Experimental Botany 40: 593-98.

[5] Arin, L., Polat, S., Devcci, M., Salk, A. (2011): Effect of different osmotic solutions on onion seed emergence. - African Journal of Agriculture Research 6: 986-91.

[6] Bailly, C., Bogatek-Leszczynska, R., Côme, D., Corbineau, F. (2002): Changes in activities of antioxidant enzymes and lipoxygenase during growth of sunflower seedlings from seeds of different vigour. - Seed Science Research 12: 47-55.

[7] Barea, J. M., Brown, M. E. (1974): Effect on plant growth produced by A. paspali related to the synthesis of plant growth regulating substance. - Journal of Applied Bacteriology 37: 583-93.

[8] Bashan, Y., Holguin, K., de-Bashan, L. E. (2004): Azospirillum-plant relationships: physiological, molecular, agricultural and environmental advances. - Canadian Journal of Microbiology 50: 521-77.

[9] Basra, S. M. A., Ullah, E., Warraich, E. A., Cheema, M. A., Afzal, I. (2003): Effect of storage on growth and yield of primed canola (Brassica napus) seeds. - International Journal of Agriculture and Biology 5: 117-20.

[10] Borowski, E., Michałek, S. (2006): The effect of seed conditioning on the emergence and early growth of onion and carrot seedlings. - Annales Universitatis Mariae Curie-Skłodowska Setio EEE 16: 119-29.

[11] Bosland, P. W., Votara, E. J. (2000): Peppers: Vegetable and Spice Capsicums. - CABI Publishing, New York.

[12] Bradford, K. J. (1986): Manipulation of seed water relations via osmotic priming to improve germination under stress conditions. - Horticultural Science 21: 1105-12. 
[13] Brar, N. S., Thakur, K. S., Kumar, R., Mehta, D. K. (2015): Yield and quality of tomato seed and soil fertility as affected by organic manures and biofertilizers. - Green Farming 6: 1068-70.

[14] Brar, N. S., Kaushik, P., Dudi, B. S. (2019): Assessment of natural ageing related physiobiochemical changes in onion seed. - Agriculture 9: 163.

[15] Brown, M. E. (1982): Nitrogen Fixation by Free-Living Bacteria Associated with Plants-Fact or Fiction? - In: Rhodes-Roberts, M., Skinner, F. A. (eds.) Bacteria and Plants. Academic Press, London. pp 255-42.

[16] Butler, L. H., Hay, F. R., Ellis, R. H., Smith, R. D., Murray, T. B. (2009): Priming and redrying improve the survival of mature seeds of Digitalis purpurea during storage. Annals of Botany 103: 1261-70.

[17] Byrum, J. R., Copeland, L. O. (1995): Variability in vigour testing of maize (Zea mays L.) seed. - Seed Science and Technology 23: 543-49.

[18] Chiu, K. Y., Chuang, S. J., Sung, J. M. (2006): Both anti-oxidation and lipid carbohydrate conversion enhancements are involved in priming improved emergence of Echinacea purpurea seeds that differ in size. - Scientia Horticulture 108: 220-26.

[19] Dadlani, M., Agrawal, P. K. (1987): Techniques in Seed Science and Technology. South Asian Publishers, New Delhi, pp. 103-104.

[20] Davison, P. A., Bray, C. M. (1991): Protein synthesis during osmopriming of leek (Allium porrum L.) seeds. - Seed Science Research 1: 29-35.

[21] Dell'Aquila, A., Corona, M. G., Turi, M. D. (1998): Heat-shock proteins in monitoring aging and heat-induced tolerance in germinating wheat and barley embryos. - Seed Science Research 8: 91-98.

[22] Doijode, S. D. (1988): Comparison of storage of French bean seeds under ambient conditions. - Seed Research 16: 245-47.

[23] Drew, R. L. K., Hands, L. J., Gray, D. (1997): Relating the effects of priming to germination of unprimed seeds. - Seed Science and Technology 25: 537-48.

[24] FAO (2017): http://www.fao.org/faostat/en/\#data/QC. - FAO, Rome.

[25] Fibach-Paldi, S., Burdman, S., Okon, Y. (2012): Key physiological properties contributing to rhizosphere adaptation and plant growth promotion abilities of Azospirillum brasilense. - Microbiology Letters 326: 99-108.

[26] Giri, G. S., Schillinger, W. F. (2003): Seed priming winter wheat for germination, emergence and yield. - Crop Science 43: 2135-41.

[27] Hafeez, F. Y., Safdar, M. E., Chaudhry, A. U., Malik, K. A. (2004): Rhizobial inoculation improves seedling emergence, nutrient uptake and growth of cotton. - Australian Journal of Experimental Agriculture 44: 617-22.

[28] Helaly, A. A., Abdelghafar, M. S., Al-Abd, M. T., Alkharpotly, A. A. (2016): Effect of soaked Allium cepa L. bulbs in growth regulators on their growth and seed production. Advances in Plants and Agricultural Research 4: 283-88.

[29] Hsu, C. C., Chen, C. L., Chen, J. J., Sung, J. M. (2003): Accelerated ageing enhanced lipid peroxidation in the bitter gourd seeds and effects of priming and hot water soaking treatments. - Scientia Horticulture 98: 201-12.

[30] ISTA (2015): International Rules for Seed Testing. - International Seed Testing Association, Bassersdorf, Switzerland.

[31] Jett, L. W., Welbaum, G. E., Morse, R. D. (1996): Effect of matric and osmotic priming treatments on Broccoli seed germination. - Journal of American Society for Horticultural Science 121: 423-29.

[32] Khajeh-Hosseini, M., Powell, A. A., Bingham, I. J. (2003): The interaction between salinity stress and seed vigour during germination of soyabean seeds. - Seed Science and Technology 31: 715-25.

[33] Khan, A. A. (1992): Preplant physiological seed conditioning. - Horticulture Review 13: $131-81$ 
[34] Khan, M., Javed Iqbal, M., Abbas, M., Raza, H., Waseem, R., Arshad, A. (2004): Loss of vigour and viability in aged onion (Allium cepa L.) seeds. - International Journal of Agriculture and Biology 6: 708-71.

[35] Kumar, R., Nagarajan, S., Rana, S. C. (2004): Effect of natural ageing under controlled storage on seed quality and yield performance of field pea cv. DMR-7. - Seed Research 32: 96-97.

[36] Lai, W. A., Rekha, P. D., Arun, A. B., Young, C. C. (2008): Effect of mineral fertilizer, pig manure, and Azospirillum rugosum on growth and nutrient contents of Lactuca sativa L. - Biology and Fertility of Soils 45: 155-64.

[37] Maguire, J. D. (1962): Speed of germination aid in selection and evaluation for seedling emergence and vigour. - Crop Science 2: 176-77.

[38] McDonald, Jr. M. B. (1980): Assessment of seed quality. - Horticultural Science 15: 78488.

[39] Moore, R. P. (1973): Tetrazolium Stain for Assessing Seed Quality. - In: Heydecker, W. (eds.) Seed Ecology. The Pennsylvania State Univ., Univ. Park, PA, pp. 347-366.

[40] Moosavi, A., Tavakkol Afshari, R., Sharif-Zadeh, F., Aynehband, A. (2009): Effect of seed priming on germination characteristics, polyphenoloxidase, and peroxidase activities of four amaranth cultivars. - Journal of Food, Agriculture and Environment 7: 353-58.

[41] Muruli, C. N., Bhanuprakash, K., Channakeshava (2016): Impact of seed priming on vigour in onion (Allium cepa L.). - Journal of Applied Horticulture 18: 68-70.

[42] Nego, J., Dechassa, N., Dessalenge, L. (2015): Effect of seed priming with potassium nitrate on bulb yield and seed quality of onion (Allium cepa L.) under rift valley conditions, Central Ethiopia. - International Journal of Crop Science and Technology 1: $1-12$.

[43] Osborne, D. J. (1983): Biochemical control systems operating in the early hours of germination. - Canadian Journal of Botany 61: 3568-77.

[44] Owen, P. L., Pill, W. G. (1994): Germination of osmotically primed asparagus and tomato seeds after storage up to three months. - Journal of American Society of Horticultural Science 119: 636-41.

[45] Patil, B. D., Manjare, M. R. (2013): Effect of seed priming on germination and bulb yield in onion (Allium cepa L.). - Ecology, Environment and Conservation 19: 243-46.

[46] Ramadevi, V., Gopalkrishnan, P. K. (2001): Studies on the Effect of Pre-Sowing Hardening Treatment on Germination and Vegetative Growth of Cowpea (Var. V-118). In: Dwivedi, R. S., Singh, R. S. (eds.) Plant Physiological Paradigm for fostering Agro and Biotechnology and Augmenting Environmental Productivity. Proc. Nat. Seminar. Indian Soc. Plant Physiol. Lucknow, 7-9 Nov., 2000, pp. 149-152.

[47] Rood, S. B., Buzzell, R. I., Major, D. J., Pharis, R. P. (1990): Gibberellins and heterosis in maize: quantitative relationship. - Crop Science 30: 281-86.

[48] Sadeghian, S. Y., Yavari, N. (2004): Effect of water-deficit stress on germination and early seedling growth in sugar beet. - Journal of Agronomy and Crop Science 190: 13844.

[49] Saranya, N., Renugadevi, J., Raja, K., Rajashree, V., Hemalath, G. (2017): Seed priming studies for vigour enhancement in onion CO onion (5). - Journal of Pharmacognosy and Phytochemistry 6: 77-82.

[50] Selvarani, K., Umarani, R. (2011): Evaluation of seed priming methods to improve seed vigour of onion (Allium cepa cv. aggregatum) and carrot (Daucus carota). - Journal of Agricultural Technology 7: 857-67.

[51] Shende, S. T., Apte, R., Singh, T. (1977): Influence of Azotobacter on germination of rice on cotton seeds. - Current Science 46: 675-76.

[52] Singh, B. G. (1995): Effect of hydration-dehydration seed treatments on vigour and yield of sunflower. - Indian Journal of Plant Physiology 38: 66-68.

[53] Taiz, L., Zeiger, E. (1991): Plant Physiology. - The Benjamin/Cumming Publishing Company. Inc., New York. 
[54] Taylor, A. G., Allen, P. S., Bennett, M. A., Bradford, K. J., Burris, J. S., Misra, M. K. (1998): Seed enhancements. - Seed Science Research 8: 245-56.

[55] Weiss, D., Ori, N. (2007): Mechanisms of cross talk between gibberellin and other hormones. - Plant Physiology 144: 1240-46.

[56] Yari, L., Khazaei, F., Sadeghi, H., Sheidaei, S. (2011): Effect of seed priming on grain yield and yield components of bread wheat (Triticum aestivum L.). - Journal of Agriculture and Biological Sciences 6: 1-5.

[57] Yarnia, M., Farajzadeh, E., Tabrizi, M. (2012): Effect of seed priming with different concentration of $\mathrm{GA}_{3}$, IAA and kinetin on Azarshahar onion germination and seedling growth. - Journal of Basic and Applied Science Research 2: 2651-61. 